\title{
Irrigation of Castor Bean (Ricinus communis L.) and Sunflower (Helianthus annus L.) Plant Species with Municipal Wastewater Effluent: Impacts on Soil Properties and Seed Yield
}

\author{
Michalis K. Chatzakis ${ }^{1}$, Vasileios A. Tzanakakis ${ }^{1, *}$, Duncan D. Mara ${ }^{2}$ and Andreas N. Angelakis ${ }^{1}$ \\ 1 Institute of Iraklion, National Agricultural Research Foundation (N.AG.RE.F.), Iraklion 71307, \\ Greece; E-Mails: cen4mc@leeds.ac.uk (M.K.C.); info@a-angelakis.gr (A.N.A.) \\ 2 Department of Civil Engineering, University of Leeds, Leeds LS2 9JT, UK; \\ E-Mail: D.D.Mara@leeds.ac.uk \\ * Author to whom correspondence should be addressed; E-Mail: vetzanakakis@cyta.gr; \\ Tel.: +30-6977441455.
}

Received: 3 October 2011; in revised form: 8 November 2011 / Accepted: 14 November 2011 / Published: 24 November 2011

\begin{abstract}
The effects of plant species (castor bean (Ricinus communis L.) versus sunflower (Helianthus annus L.)) and irrigation regime (freshwater versus secondary treated municipal wastewater) on soil properties and on seed and biodiesel yield were studied in a three year pot trial. Plant species were irrigated at rates according to their water requirements with either freshwater or wastewater effluent. Pots irrigated with freshwater received commercial fertilizer, containing $\mathrm{N}, \mathrm{P}$, and $\mathrm{K}$, applied at the beginning of each irrigation period. The results obtained in this study showed that irrigation with effluent did not result in significant changes in soil $\mathrm{pH}$, soil organic matter (SOM), total kjeldahl nitrogen (TKN), and dehydrogenase activity, whereas soil available $\mathrm{P}$ was found to increase in the upper soil layer. Soil salinity varied slightly throughout the experiment in effluent irrigated pots but no change was detected at the end of the experiment compared to the initial value, suggesting sufficient salt leaching. Pots irrigated with effluent had higher soil salinity, P, and dehydrogenase activity but lower SOM and TKN than freshwater irrigated pots. Sunflower showed greater SOM and TKN values than castor bean suggesting differences between plant species in the microorganisms carrying out $\mathrm{C}$ and $\mathrm{N}$ mineralization in the soil. Plant species irrigated with freshwater achieved higher seed yield compared to those irrigated with effluent probably reflecting the lower level of soil
\end{abstract}


salinity in freshwater irrigated pots. Castor bean achieved greater seed yield than sunflower. Biodiesel production followed the pattern of seed yield. The findings of this study suggest that wastewater effluent can constitute an important source of irrigation water and nutrients for bioenergy crop cultivations with minor adverse impacts on soil properties and seed yield. Plant species play an important role with regard to the changes in soil properties and to the related factors of seed and biodiesel yields.

Keywords: wastewater reuse; land application; bioenergy crops

\section{Introduction}

There is a growing interest worldwide with regard to the use of renewable energy sources as a mean to both reduce the environmental pollution associated with energy produced by fossil fuels and to tackle the problem of the depletion of these fuels. At present, in the European Union (EU) renewable energy sources account for only $4.5 \%$ of the total energy consumption, however, a target of $20 \%$ has been set for 2020. In addition, it is hoped to increase biofuel consumption to $10 \%$ of the fuels used in road transportation by 2010 [1]. The increase in biofuel production is expected to offer environmental and economic benefits to European communities by promoting rural employment and incomes, reducing greenhouse gas (GHG) emissions, and by improving energy supply and security. The most common biofuels are biodiesel and bioethanol, mainly produced from biomass or renewable energy sources, with biodiesel representing $82 \%$ of the total biofuel production in the EU [2].

Currently, the major biodiesel feedstocks are edible-grade vegetable oils originating mainly from soybeen, rapeseed, sunflower, mustard, and palm. A major drawback of these bioenergy crops is the fact that the intensive cultivation and large scale production of vegetable oils for biodiesel production leads to significant increases in oil prices and an imbalance in the food market, particularly in developing countries. Moreover, these crops may compete with traditional food crops for land and available water. In order to mitigate these problems, unconventional bioenergy crops and the oilseeds produced are being investigated as alternative feedstocks. Castor bean (Ricinus communis L.) is considered to be one of the most promising non-edible oil crops due to its high potential for annual seed production and its tolerance to diverse environmental conditions. In addition, castor bean can be grown on marginal lands which are usually unsuitable for food crops [3-5].

The establishment of bioenergy crops in marginal or degraded lands may offer additional environmental benefits, such as protection from soil erosion and nutrient leaching, and improvement of soil properties [6]. Of particular interest is the use of bioenergy crops as a vegetative filter to purify wastewater effluents applied to the soil. This practice is also known as land treatment systems (LTS) or slow rate systems (SRS) and meets both environmental and renewable bioenergy goals [7,8]. Effluent can supply bioenergy crops with considerable amounts of water and nutrients which stimulate plant growth and yield. In addition, effluent application can reduce the competition between bioenergy crops and traditional crops with respect to the use of fresh water, and it can also decrease production cost due to substitution of water and fertilizers [9]. 
The irrigation of bioenergy crops with wastewater effluent gives rise to serious environmental concerns which need to be addressed. The prime concern regards the release of nutrients to the environment, particularly nitrogen $(\mathrm{N})$ and phosphorus $(\mathrm{P})$, and their potential to adversely affect the quality of water resources and the climate due to the accumulation of nitrates/phosphates in the soil and the increase in greenhouse gaseous emissions (e.g., $\mathrm{N}_{\mathrm{x}} \mathrm{O}$ ) [10-12]. Crops play a defining role in $\mathrm{N}$ cycling with effects on the effluent application rates and the amount of $\mathrm{N}$ entering the soil, the proportion of $\mathrm{N}$ recovered, and microbial communities mediating $\mathrm{N}$ turnover in the soil [13-15]. With regard to $\mathrm{P}$, however, the effect of crops becomes less strong because of the catalytic role of soil on the sorption and transfer of $\mathrm{P}$ and the relatively low potential of crops for $\mathrm{P}$ assimilation in plant biomass $[15,16]$. Recent work has shown that the selection of crops with high water use efficiency (WUE), as determined by low biomass potential, and the adoption of appropriate management practices may reduce $\mathrm{N}$ and $\mathrm{P}$ release to the environment in sites irrigated with relative strong effluent [15].

Wastewater effluent may result in significant changes in soil properties, thus influencing the overall functioning of the soil [16]. Increased levels of soil salinity and sodicity and adverse changes in physical properties have been reported in sites under effluent application in range dependent on the quality of effluent, irrigation rates, and soil properties $[7,17,18]$. Soil microorganisms and enzymes activities have been found to respond rapidly to these changes [19,20]. Enhanced activities are often attributed to the organic matter and nutrients from wastewater effluent, whereas the adverse effects are associated with the presence of harmful constituents in the effluent, such as heavy metals or aromatic polycyclic hydrocarbons. Among enzymes, dehydrogenase, which is an important intracellular enzyme in metabolic reactions in living soil microbes, is considered to be an appropriate indicator of microbial activity in soils treated with effluent or other polluted waters [20].

The effects of plant species (Ricinus communis L. versus Helianthus annus L.) and irrigation regime (freshwater versus secondary treated municipal wastewater) on soil properties and on seed and biodiesel yields were studied in a three year pot trial. Knowledge provided from this study is expected to help in the better understanding of the soil and yield response of bioenergy crops grown under different irrigation regimes, particularly those irrigated with wastewater effluent, leading to suitable plant species and better irrigation water/wastewater effluent management, ensuring sustainable yield with minor adverse environmental impacts.

\section{Materials and Methods}

The study was carried out in an experimental field of NAGREF in Iraklion, Crete-Greece. The climate is semi-arid with relatively humid winters and dry, warm summers. Meteorological data (temperature and rainfall) were obtained from a station next to the experimental field and are shown in Figure 1. In May 2007, seeds of castor bean (Ricinus communis) and sunflower (Helianthus annus) were planted in large pots $(40 \mathrm{~cm}$ in diameter $\times 50 \mathrm{~cm}$ in height). Previously, the pots were filled with top-soil from an adjacent fallow field and were placed in a square of $1 \mathrm{~m}$ intervals. The soil was characterized as clay-loamy (CL) (Sand 39\%, loam 28\%, and clay 33\%) and the chemical properties were $\mathrm{pH}: 7.81$, electrical conductivity $(\mathrm{EC})(\mathrm{dS} / \mathrm{m}): 0.40$, soil organic matter $(\mathrm{SOM})(\%): 2.40$, total kjeldahl nitrogen (TKN) (\%): 0.19, Olsen-P (ppm): 24.00. Plant species were irrigated with secondary treated wastewater effluent or freshwater and were arranged in a randomized complete block design 
with three treatments (plant species (2), water quality (2), and soil depth (3)) and seven replicates. Pots were located at a distance of $1 \mathrm{~m}$ from each other. The experiment was conducted for three consecutive growing seasons (2007-2009) and at the end of each season plant species were removed from the pots and replaced with new seeds at the beginning of the next season.

Figure 1. Temperature and rainfall during the experimental period.

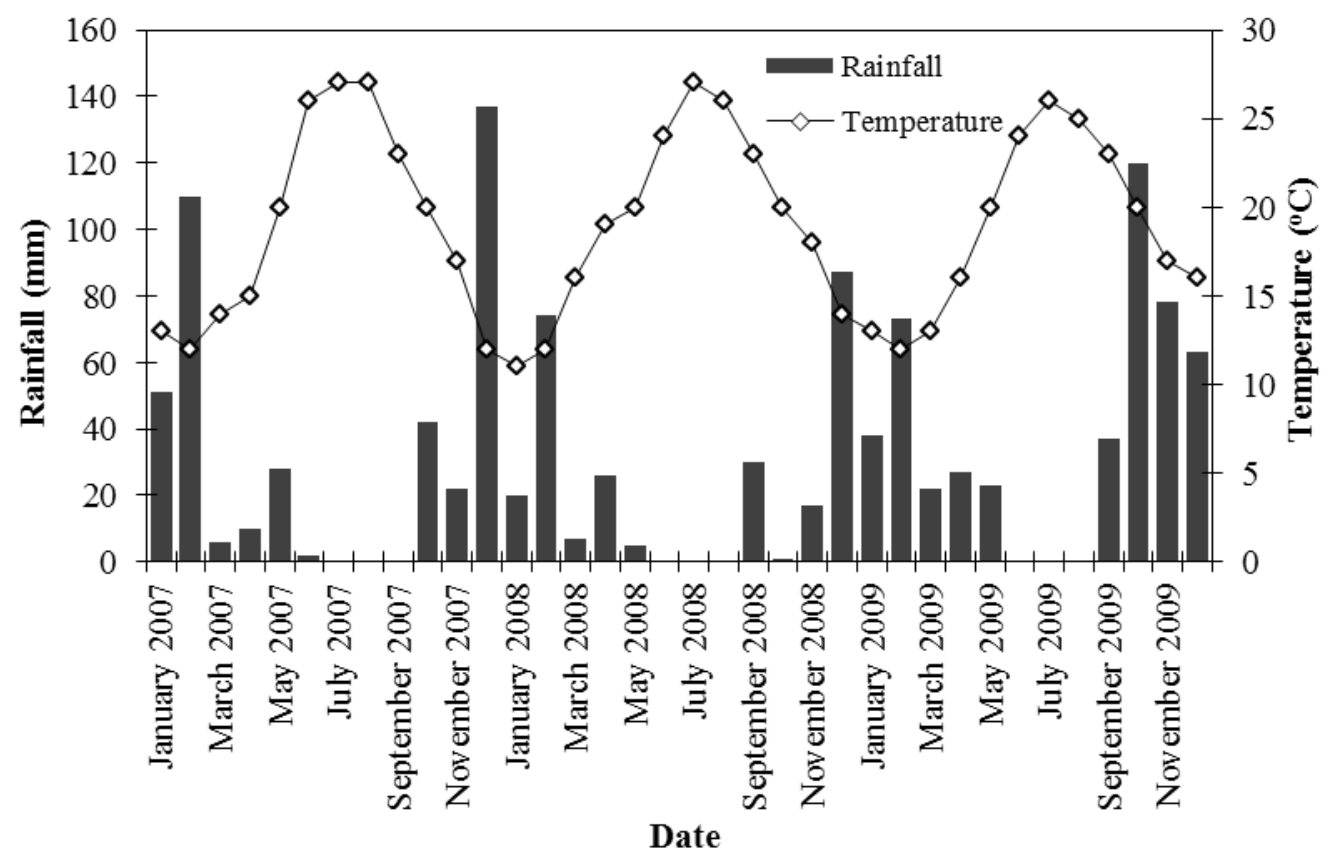

The effluent used in this study was collected from the biological treatment unit of the city of Iraklion on a weekly basis and was transferred through a plastic tank to the experimental field, where it was discharged and stored in a $500 \mathrm{~L}$ tank. The freshwater used was supplied from the irrigation system of NAGREF. The average composition of the effluent and freshwater applied to the pots is shown in Table 1. The application rates of the effluent and freshwater were based on crop water requirements estimated separately for each plant species using tensiometers reading from depth of $30 \mathrm{~cm}$. The soil water potential was never allowed to fall below $-40 \mathrm{kPa}$ so that irrigated crops did not experience water stress. The hydraulic loading rates applied in this study were higher than those of reference evapotranspiration of the area [15] due to higher soil temperature since the pots were exposed to the sun. The application of effluent and freshwater was carried out manually with the use of volumetric flasks so that equal quantities of liquid were applied to all pots in every wet-dry cycle. The differentiation of the hydraulic load among different plant species is due to variations in the irrigation frequency resulting from different growth pattern and water needs. The method of application was thoroughly tested with freshwater during its establishment and at the beginning of every growing season to validate that flow was uniform within pots. The pots treated with freshwater also received commercial fertilizer, containing $\mathrm{N}, \mathrm{P}$, and $\mathrm{K}$, applied at the beginning of each irrigation period. The planning of fertilization was mainly to achieve equal amount of nitrogen added between effluent and freshwater pots. The effluent and freshwater loads as well as the amount of N, P and COD applied to each plant species at the end of the three growing seasons are given in Table 2. 
Table 1. Average values of chemical parameters in freshwater and effluent samples.

\begin{tabular}{lcc}
\hline Parameter & Freshwater & Effluent \\
\hline $\mathrm{pH}$ & 7.48 & 7.59 \\
$\mathrm{EC}(\mathrm{dS} / \mathrm{m})$ & 1.38 & 2.28 \\
$\mathrm{COD}(\mathrm{mg} / \mathrm{L})$ & $<1$ & 40.00 \\
$\mathrm{TP}(\mathrm{mg} / \mathrm{L})$ & 0.80 & 2.80 \\
$\mathrm{TKN}(\mathrm{mg} / \mathrm{L})$ & $<1$ & 18.40 \\
\hline
\end{tabular}

Table 2. Hydraulic, N, P, and COD loads applied to freshwater and effluent irrigated pots.

\begin{tabular}{ccccc}
\hline $\begin{array}{c}\text { Water quality/plant } \\
\text { species/irrigation periods }\end{array}$ & $\begin{array}{c}\text { Freshwater/effluent } \\
(\mathbf{m m})\end{array}$ & $\begin{array}{c}\mathbf{N} \\
\mathbf{( k g} / \mathbf{h a})\end{array}$ & $\begin{array}{c}\mathbf{P} \\
\mathbf{( k g} / \mathbf{h a})\end{array}$ & $\begin{array}{c}\text { COD } \\
\mathbf{( k g} / \mathbf{h a})\end{array}$ \\
\hline FH 07 & 1,904 & 285.0 & 281.2 & - \\
FH 08 & 1,173 & 277.7 & 275.4 & - \\
FH 09 & 1,587 & 281.8 & 278.7 & - \\
FR 07 & 1,736 & 283.4 & 279.9 & - \\
FR 08 & 1,118 & 277.2 & 274.9 & - \\
FR 09 & 1,609 & 282.1 & 278.9 & - \\
WH 07 & 1,679 & 308.9 & 47.0 & 671.5 \\
WH 08 & 1,088 & 200.3 & 30.5 & 435.4 \\
WH 09 & 1,460 & 268.7 & 40.9 & 584.2 \\
WR 07 & 1,433 & 263.7 & 40.1 & 573.2 \\
WR 08 & 913 & 168.1 & 25.6 & 365.3 \\
WR 09 & 1,326 & 244.0 & 37.1 & 530.5 \\
\hline
\end{tabular}

F: fresh water; W: wastewater; H: Helianthous annus; R: Ricinus communis; 07, 08, and 09: irrigation periods.

Samples of effluent and fresh water were collected from the outlet of storage tanks, on a weekly basis, transferred to the laboratory, and analyzed for $\mathrm{pH}, \mathrm{EC}, \mathrm{TKN}$, total phosphorous (TP), and COD. Sample preparation and the relevant analyses were done according to Standard Methods for the Examination of Water and Wastewater [21]. In addition, soil samples from 0-10, 10-20, and 20-30 cm depths were collected at the beginning and at the end of each irrigation period from each pot with the aid of a soil sampler. All samples were air-dried at room temperature for no less than 4 weeks each time. The dried samples were then ground to dust, sifted through $1 \mathrm{~mm}$ sieves and analyzed for $\mathrm{pH}, \mathrm{EC}$, TKN, Olsen-P, and SOM according to methods of soil analysis [22]. The particle size analysis of the soil samples was carried out by the Bouyoucos hydrometer method. Measurements of $\mathrm{pH}$ and EC were carried out in saturation paste extracts. The Walkley and Black wet digestion method was used for the determination of organic matter (SOM) in soil samples. Available-P was assessed after extraction with $\mathrm{NaHCO}_{3}$ according to the Olsen method. Total kjeldahl nitrogen (TKN) was assessed by a micro-kjeldahl device. Soil samples for the examination of dehydrogenase activity were immediately stored at $4{ }^{\circ} \mathrm{C}$. The dehydrogenase activities were measured by a slightly modified method of [23] within two weeks after the soil collection, as follows. Fresh soil (2.5 g) was added to a test tube $(18 \mathrm{~mm} \times 150 \mathrm{~mm})$ and mixed with $2.5 \mathrm{~mL}$ of $1 \%$ TTC (2,3,5-triphenyl tetrazolium chloride)-Tris buffer ( $\mathrm{pH}$ 7.6). The tubes were incubated at $37{ }^{\circ} \mathrm{C}$ in the dark for $24 \mathrm{~h}$. The triphenylformazan (TPF) 
formed by the reduction of TTC was extracted with $50 \mathrm{~mL}$ methanol and measured with a spectrophotometer at $485 \mathrm{~nm}$. Methanol was used as a blank.

In this study, growth, seed yield, oil content, and biodiesel production were estimated so as to compare different water qualities and crops. Therefore, all plants were cut down every year at the end of each irrigation period following the collection of the seeds. Height was measured from the soil level to the last part of the plant which was the back of the head for sunflower and the last blossom for castor bean. The seeds form each plant were collected every year at the end of the irrigation period or at the time when they were ready for harvesting, the sunflower seeds were cut down before the end of the irrigation period since they reached maturity before castor bean plants. After collection, seeds were air dried for two weeks at room temperature and then weighed. For the calculation of seed yield in $\mathrm{kg}$ per ha a spacing of $40 \times 40 \mathrm{~cm}$ was considered including 62,500 plants per ha which is normal for castor or sunflower plantations [24,25]. Samples of seeds were sent to the lab of the Technical University of Crete for oil and biodiesel extraction. Assessment of biodiesel yield was based on the amount of seeds yielded, the quantity of oil that was extracted from the seeds, and the percentage of biodiesel reclamation from the oil. For the oil extraction process 1:6 m/v (mass per volume) seed to solvent ratio was used [26]. The synthesis of biodiesel was by the homogeneous base transesterification method using sodium hydroxide as a catalyst.

Statistical analysis was performed using SPSS 17.0 program. Analysis of variance (ANOVA) was used for data analysis. Post hoc pair wise comparisons among plant species, water qualities or soil depths were examined by Tukey's honestly significant difference (HSD) test.

\section{Results}

\subsection{Impacts on Soil Properties}

Irrigation with freshwater and effluent tended to increase soil $\mathrm{pH}$ in all soil layers over the first and second irrigation period but then it decreased slightly in the upper soil layers towards the end of the experiment. In contrast, soil $\mathrm{pH}$ in the deeper soil layer continued to increase during the last period and as a result of this trend a significant effect was detected in that period, with the deepest soil layer showing higher $\mathrm{pH}$ values compared to those of the upper ones.

Pots irrigated with effluent were found to have slightly higher soil $\mathrm{pH}$ compared to those irrigated with freshwater, an effect which appeared at the beginning of the second irrigation period and peaked at the end of that period. Thereafter, the differences in soil $\mathrm{pH}$ between effluent and freshwater treated pots decreased with time. Furthermore, plant species had no significant effect on soil $\mathrm{pH}$ during the experimental period.

With regard to soil EC, it increased slightly during irrigation periods and reduced during the winter. Thus, no change was detected at the end of the experiment compared to the initial value, suggesting sufficient salt leaching. Pots irrigated with effluent had higher EC compared to those irrigated with freshwater throughout irrigation periods. Plant species and soil depth had no effect on the EC of soil.

SOM varied slightly during the experimental period and no change of the initial value was detected at the end of the experiment. In pots irrigated with freshwater the SOM increased slightly during the irrigation periods but returned to background levels after each winter. With regard to effluent irrigated 
pots, SOM remained almost constant during the experimental period. As a result of these trends, SOM was marginally higher in pots irrigated with freshwater compared to pots irrigated with effluent at the end of irrigation periods but this effect tended to decline after the winter (Figure 2a). As with water quality, plant species significantly affected SOM, with sunflower showing greater values than castor bean during the second and third irrigation periods (Figure 2a). No differences in SOM were detected among different soil layers.

Figure 2. Average values of (a) soil organic matter (SOM); and (b) total kjeldahl nitrogen (TKN) as a function of water quality and plant species, during the three irrigation periods (2007-2009).

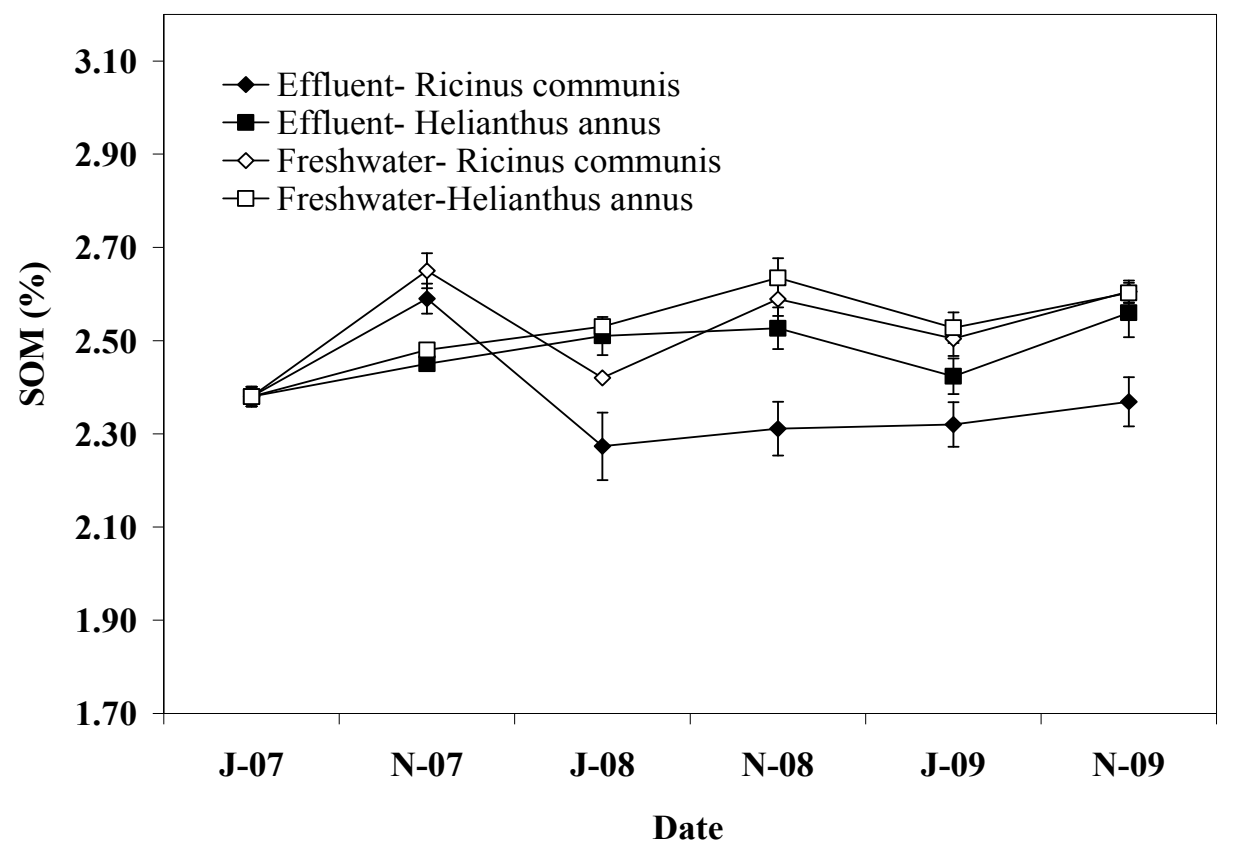

(a)

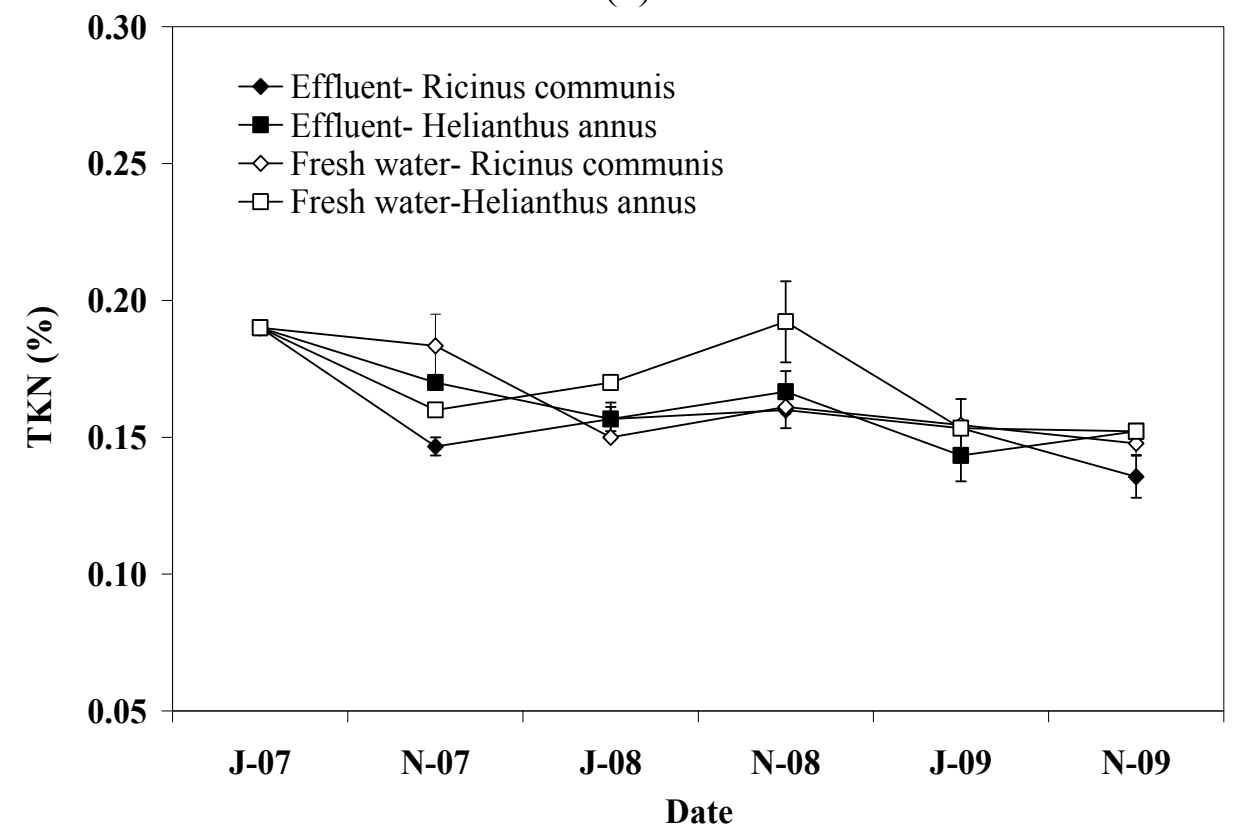

(b) 
With the exception of the second irrigation period, soil TKN decreased slightly in all pots during the experimental period. It was marginally higher in pots irrigated with freshwater than in effluent irrigated pots (Figure $2 \mathrm{~b}$ ). This effect was evident mainly in pots planted with sunflower and it became stronger towards the end of the second irrigation period (Figure 2b). Soil depth had no significant effect on soil TKN, although plant species with sunflower showed higher TKN compared to castor bean.

Those pots irrigated with effluent showed only a slight variation in soil P levels, the final amounts being close background levels (Figure $3 \mathrm{a}$ and $\mathrm{b}$ ). However, soil $\mathrm{P}$ followed a different pattern in pots irrigated with freshwater, a significant decrease being detected by the beginning of the second period. Thereafter no significant variation of soil $\mathrm{P}$ was observed until the end of the experimental period. As a result of these trends, soil $\mathrm{P}$ was higher in the pots irrigated with effluent than in the pots irrigated with fresh water from the beginning of the second irrigation period to the end of the experiment. No differences in soil $\mathrm{P}$ were observed among soil layers until the beginning of the second period. Thereafter it varied greatly with soil depth in all pots; the upper soil layer showing higher soil $\mathrm{P}$ than the deeper layers. An increase in soil $\mathrm{P}$ was observed in the upper soil layer in effluent irrigation pots as indicated in Figure $3 \mathrm{~b}$. With regard to plant species no significant differences in soil $\mathrm{P}$ were detected (Figure 3a).

Figure 3. Average values of soil available $\mathrm{P}$ as a function of (a) water quality and plant species; and (b) water quality and soil depth, during the three irrigation periods (2007-2009).

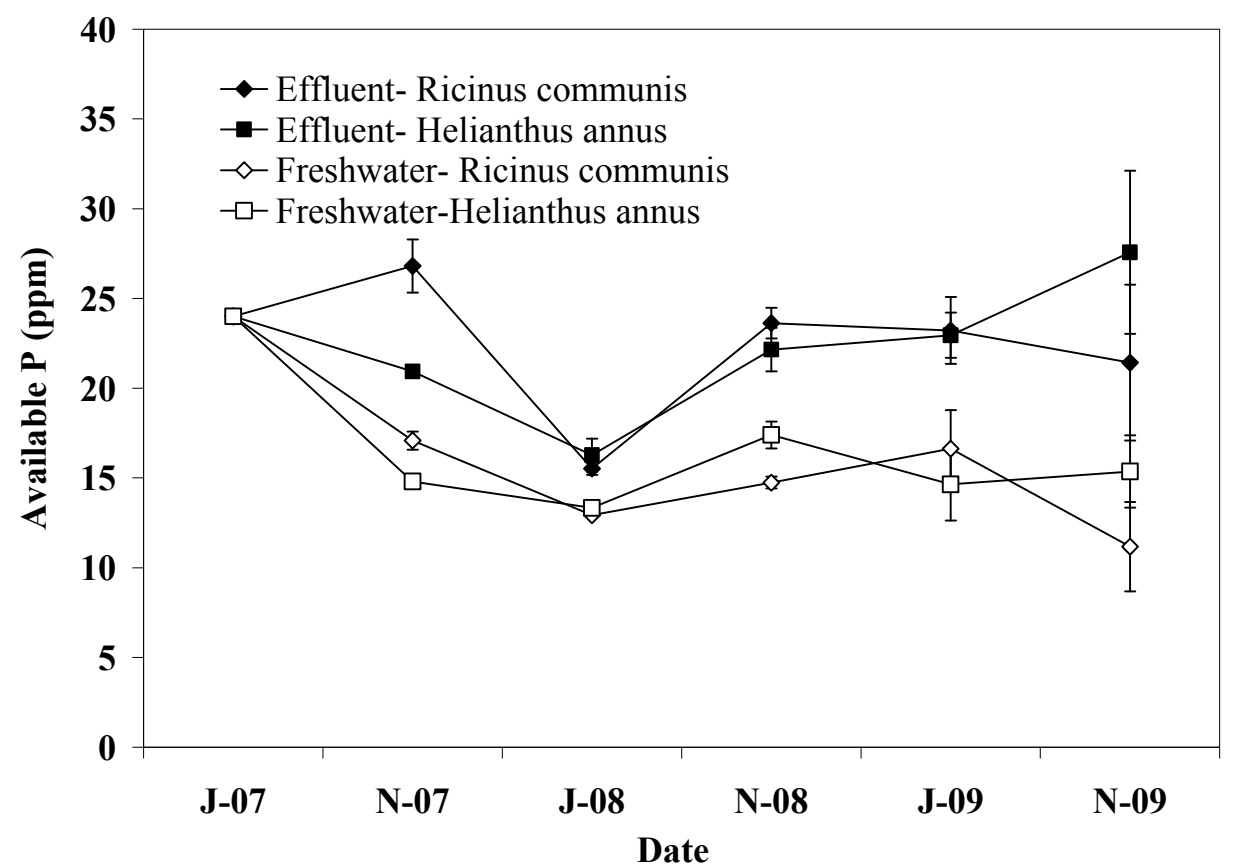

(a) 
Figure 3. Cont.

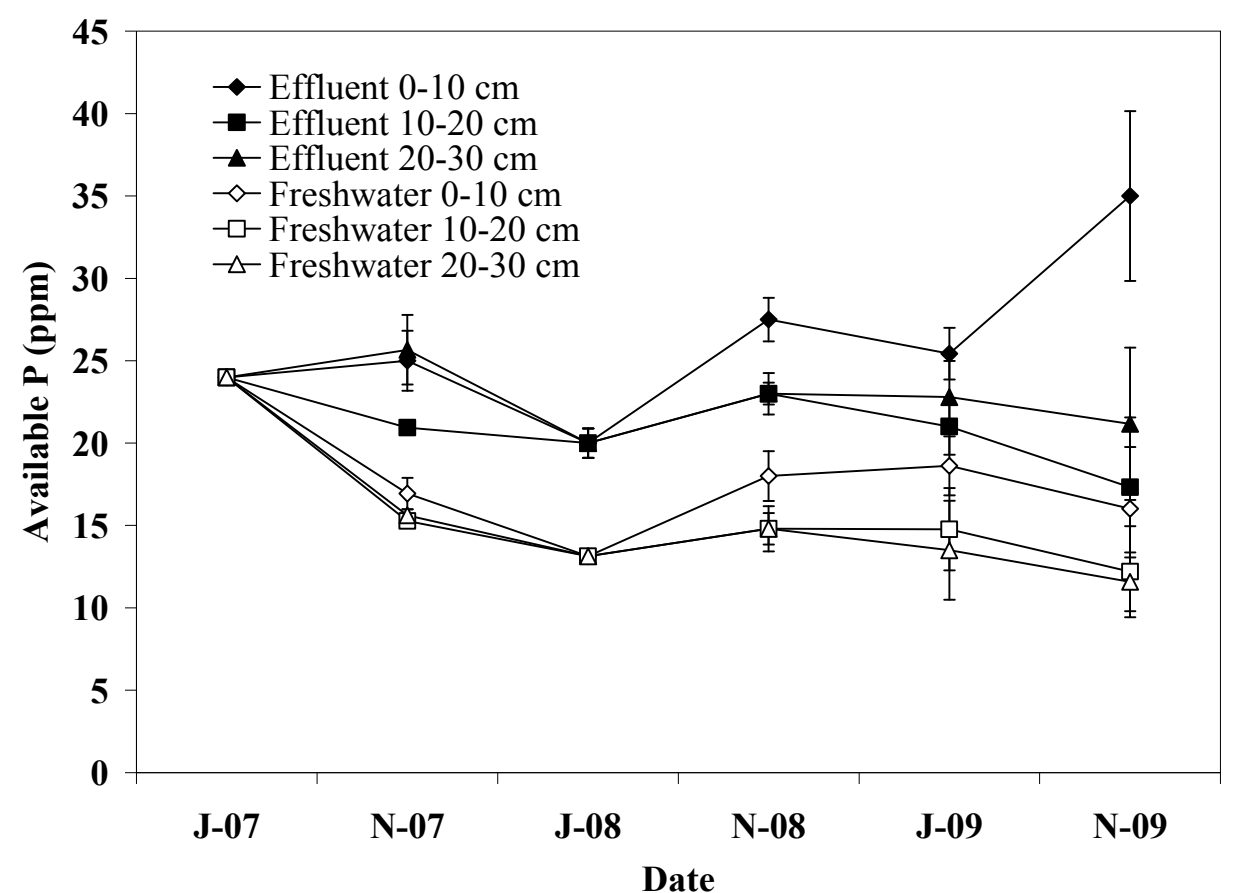

(b)

Dehydrogenase activity in the soil at the end of three consecutive irrigation periods was slightly lower than that measured at the beginning of the experiment. Soil irrigated with freshwater tended to have lower dehydrogenase activity compared to soil irrigated with effluent (Figure 4a), providing information for differences in microbial biomass and activities between pots irrigated with different irrigation regime. Soil depth had a significant effect on dehydrogenase activity with the deepest soil layer showing lower value than the upper soil layers (Figure 4b). As far as the plant species is concerned, no difference in dehydrogenase activity was detected at the end of the experimental period.

Figure 4. Dehydrogenase activity as a function of (a) water quality; and (b) soil depth, at the beginning and end of the experimental period (November 2009).

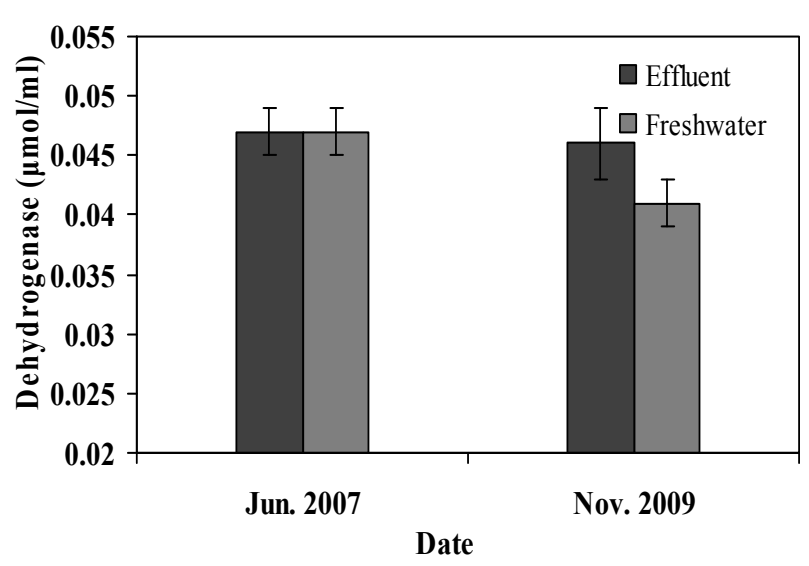

(a)

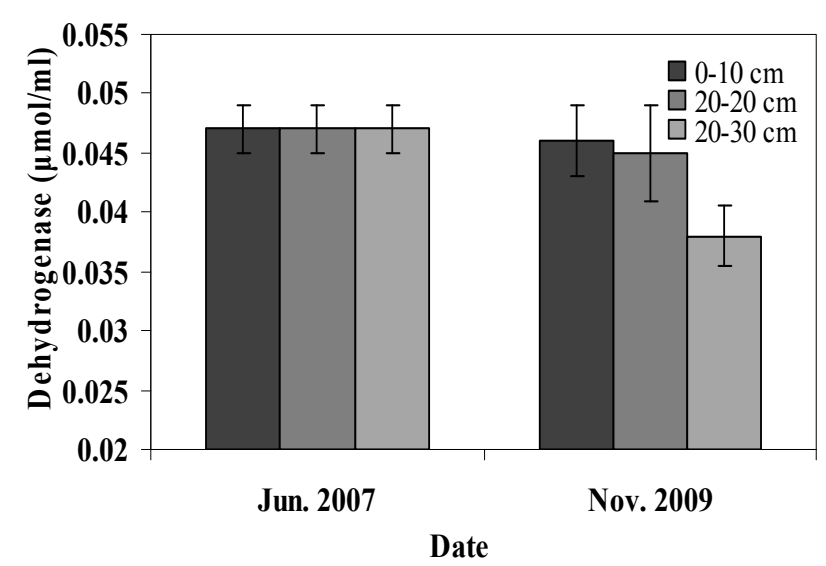

(b) 


\subsection{Plant Height, Seed Yield, and Biodiesel Production}

Water quality had no effect on the height of sunflower throughout the experimental period. In contrast, castor bean displayed sensitivity to the irrigation regime, with taller plants found in freshwater irrigated pots than in pots irrigated with effluent (Figure 5). Plant species irrigated with freshwater achieved higher seed yield compared to species irrigated with effluent. With regard to differences between plant species, castor bean showed higher seed yield than sunflower (Table 3).

Figure 5. Plant height of different plant species at the end of the three irrigation periods.

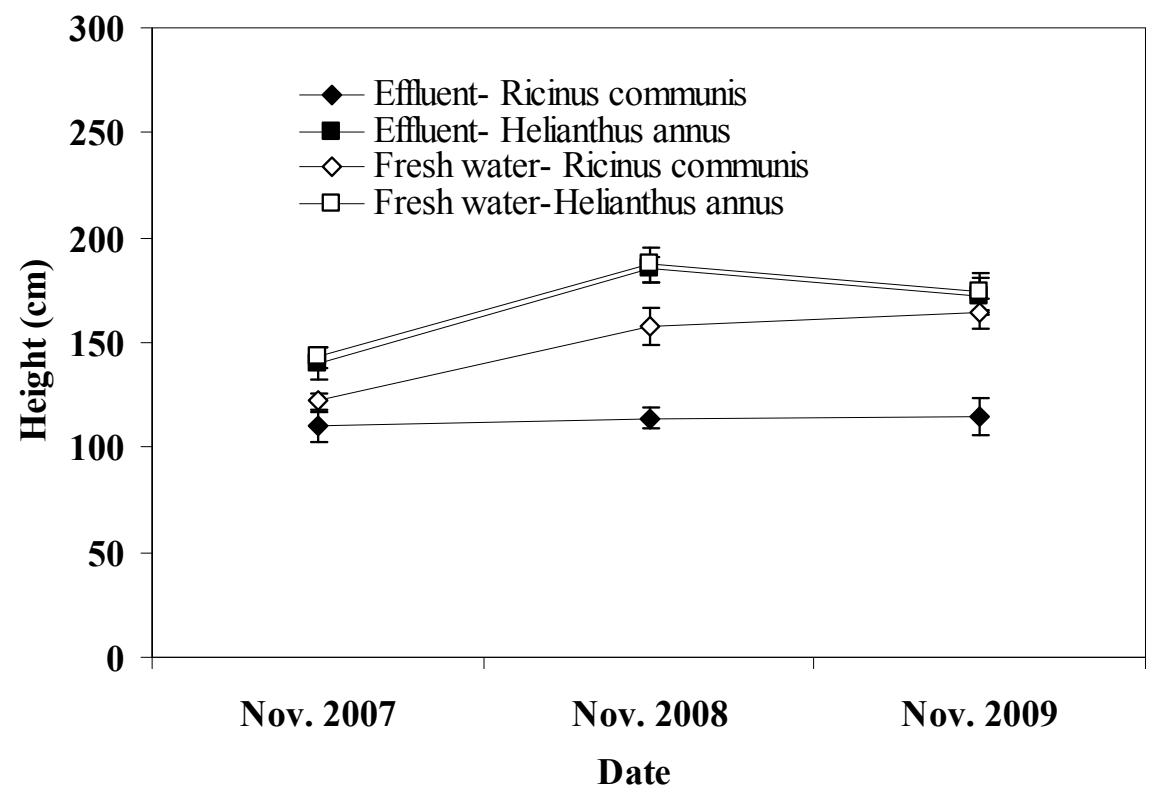

Table 3. Average values of seed, oil and biodiesel yields for different crops and irrigation regimes.

\begin{tabular}{ccccc}
\hline Treatments & kg seeds/ha yr & kg oil/ha yr & gr biodiesel/gr oil & kg biodiesel/ha yr \\
\hline FH & 5,068 & 908 & 0.63 & 572.04 \\
FR & 6,220 & 1,060 & 0.69 & 731.40 \\
WH & 4,458 & 818 & 0.68 & 556.24 \\
WR & 5,035 & 853 & 0.76 & 648.28 \\
\hline
\end{tabular}

The oil produced followed the same pattern as that of seed yield. The highest percentage of reclaimed biodiesel was observed in effluent irrigated castor bean followed by freshwater irrigated castor bean, freshwater irrigated sunflower, and effluent irrigated sunflower (Table 3). As a result of the seed yields obtained and the conversion percentage of oil, the production of biodiesel varied greatly among different treatments, with freshwater irrigated pots showing higher biodiesel yields compared to effluent irrigated pots. In addition, the amount of biodiesel produced by castor bean was greater than that produced by sunflower.

\section{Discussion}

A slight increase in soil pH mainly in the deeper soil layer $(20-30 \mathrm{~cm})$ was detected only at the end of the third experimental period. Furthermore, effluent irrigated pots showed higher $\mathrm{pH}$ levels than 
pots irrigated with freshwater. These differences may be explained by variations in the levels of carbonates and bicarbonates of several cations, such as $\mathrm{Ca}^{2+}$ and $\mathrm{Na}^{+}$, which have probably accumulated in the soil [27]. The plant species had no effect on soil $\mathrm{pH}$, this fact together with the minor effects of soil depth and irrigation regime reflect the strong buffering capacity of the fine textured soil in this study.

Irrigation with water of relatively high salt content can increase the level of soil EC because of accumulation of salts in the soil. Increased levels of soil salinity may adversely affect soil properties and reduce plant growth due to declining soil osmotic potential and lower water availability [17,18]. In this study, an increase in soil EC was observed during irrigation periods, which was followed by a decrease to the background levels after the winter suggesting sufficient salt leaching. Pots irrigated with effluent were observed to have higher soil EC than those irrigated with freshwater due to the higher salt of the effluent. With regard to plant species the absence of differences at the level of soil EC might be expected due to similar application rates. Previous work has shown that the level of soil EC follows the pattern of application rate since plant species can assimilate only a proportion of the available salts $[15,16]$.

$\mathrm{SOM}$ at the end of the irrigation periods was marginally greater in pots irrigated with freshwater than in those irrigated with effluent, reflecting the high assimilation potential of soil for organic matter contained in the effluent. This result is in agreement with those reported in a previous study [28] regarding the SOM in the subsoil $(0.2-2.0 \mathrm{~m})$, which was attributed to priming effect induced by available substrate in effluent treated pots. Effluent supplies soil with organic $\mathrm{C}$, water, and nutrients which stimulate the growth and activities of microorganisms, which in turn induce decomposition of old SOM in the soil [29]. This was also indicated by the higher dehydrogenase activity in the soil of pots irrigated with effluent. In this study, soil depth had no effect on SOM due to the priming effect which probably masked potential accumulation of SOM, particularly in the upper soil layer, in effluent irrigated pots.

Plant species significantly affected SOM with pots planted with sunflower showing higher values than those planted with castor bean from the beginning of the second irrigation period to the end of the experiment. This effect was observed in both effluent and freshwater irrigated pots and could be indirect evidence for differences between plant species in root exudates and population and activity of heterotrophs mediating SOM mineralization, since there were similarities between plant species in the quality and loading of the applied effluent or freshwater (see Section 2). Previous work provided evidence that plant species, through root exudates, are able to adjust organic $\mathrm{C}$ in the rhizosphere and shape the microbial community which is sensitive to changes in soil C substrate [14]. It has been reported a variation of $20 \%$ in the $\mathrm{C}$ mineralization rate attributed to differences in the affinity between decomposers and available substrate [30]. In another study it was found that changes in plant diversity resulted in differences in the abundance, composition, and functions of microbial heterotrophic communities, leading to variations in respiration rates [31]. Moreover, plant species, through root exudates, can have a more direct effect on the concentration of SOM. For example, it has been reported that some species exude root enzymes, such as nitroreductase, dehalogenases, and laccases, which may induce the degradation of more refractory organic compounds [32]. However, such an effect was not investigated in the present study. 
Soil TKN did not follow the same pattern with SOM showing also a slight decrease throughout the experimental period. In a previous study [16] with cyclic application of pre-treated effluent in different plant species, a similar pattern for SOM and TKN was observed, suggesting that $\mathrm{C}$ and $\mathrm{N}$ mineralization is tightly linked. However, in this study, the differences between TKN pattern and that of SOM suggest that the mineralization of organic $\mathrm{N}$ in the soil may be explained by some other mechanism different to that of SOM. This suggestion is strengthened by the concentration of ammonium $\mathrm{N}$ in the soil which was expected to be relatively low due to the induced nitrification by the favorable environmental conditions [16]. Rapid $\mathrm{N}$ nitrification rates have been observed $\mathrm{n}$ sites under effluent application, which was attributed to the increased $\mathrm{C}$ and $\mathrm{N}$ availability and application of wet-dry cycles [33,34].

Soil $\mathrm{P}$ increased in the upper soil layer in pots irrigated with effluent, which is attributed to the high adsorption capacity of soil. Fine textured soils carry more sites capable of reacting with $\mathrm{P}$ and increase the interaction time between soil particles and water [27]. In freshwater irrigated pots, soil P dropped significantly during the first irrigation period showing lower values than effluent irrigated pots until the end of experiment. This effect is not consistent with the amount of $\mathrm{P}$ applied via effluent irrigation or fertilization, however, in soils with relatively high $\mathrm{P}$ content release to soil solution is likely to occur when soil is exposed to water with low $\mathrm{P}$ concentration [27,35]. No differences in soil P were detected between plant species, reflecting the similar P loading between plant species since only a small fraction of the applied $\mathrm{P}$ is recovered from plant biomass $[13,15]$.

Previous work has shown that effluent application increases enzyme activity in the soil reflecting the larger microbial communities present due to increased $\mathrm{C}$ and $\mathrm{N}$ availability $[20,36]$. In this study, differences in dehydrogenase activity were observed between effluent and freshwater irrigated pots, which is in agreement with the SOM and TKN results, suggesting differences in microbial biomass in the soil between effluent and freshwater irrigated pots. It has been found that in a dairy shed effluent irrigated soil the microbial biomass $\mathrm{C}$ and the dehydrogenase activity were elevated until day 30 of the experiment and then declined due to a decrease in soluble organic C [37]. Similar microbial biomass and dehydrogenase activity between secondary effluent irrigated soil and soil irrigated with freshwater has been reported suggesting changes only for a minor fraction of the bacterial community [36]. With regard to soil depth and its effect on dehydrogenase activity, results showed that it was similar in the upper soil layers but declined slightly at a depth of $30 \mathrm{~cm}$. Lower microbial biomass and activities expected in the deeper soil layer may account for this result [36,37]. In this study plant species had no effect on dehydrogenase activity, suggesting that the potential variations between plant species in microbial biomass and communities were not sufficient to differentiate dehydrogenase activity.

Pots irrigated with freshwater showed higher seed yield for castor bean and sunflower compared to those irrigated with effluent. The higher level of soil salinity in effluent irrigated pots may account for this effect. In addition, the potential presence of toxic materials, such as heavy metals and aromatic hydrocarbons in the effluent may have also adversely affected seed yield in effluent irrigated pots [38]. Plant species significantly affected seed yield in this study with castor bean showing greater yield compared to sunflower. Previous work provides evidence that annual seed yield varies greatly with plant species and genotypes, environmental conditions, and agronomic practices. Typical seed yield reported for castor bean ranges from 900 to $1,200 \mathrm{~kg} / \mathrm{ha}$ under irrigation with 40-60\% oil content [39]. However, a study reported annual maximum of $2000 \mathrm{~kg} / \mathrm{ha}$ with $48 \%$ oil for castor bean [40] and this 
yield is lower than that obtained in this study due to lower irrigation rates at $320 \mathrm{~mm} / \mathrm{yr}$. In Greece, seed yields up to $5,000 \mathrm{~kg} / \mathrm{ha}$ with about $50 \%$ oil content for castor bean depending on the plant genotype have been observed [41]. These seed yields are in agreement with those found in our study but they were achieved with lower water irrigation rates and $\mathrm{N}$ and $\mathrm{P}$ additions ranging from 80 to 100 $\mathrm{kg} / \mathrm{ha}$ and 18 to $48 \mathrm{~kg} / \mathrm{ha}$, respectively. However, there seems to be a ceiling in the seed yield of castor bean regardless of the fertilization rates more than $50 \mathrm{~kg} / \mathrm{ha}$ for $\mathrm{N}$ and $30 \mathrm{~kg} / \mathrm{ha}$ for $\mathrm{P}$ [42]. With regard to sunflower, its average seed yield ranges from 900 to $1,600 \mathrm{~kg} / \mathrm{ha}$ of seed with oil content ranging from 18 to $40 \%$ [43,44]. However, a higher seed yield of $4056 \mathrm{~kg} / \mathrm{ha}$ and oil yield at $1,841 \mathrm{~kg} / \mathrm{ha}$ obtained from the treatment with no water stress has been reported [45]. These values are similar to those obtained in this study reflecting the favorable environmental conditions in which crops were grown during the experimental period. With regard to biodiesel production, in this study it followed the pattern of the seed yield since it was indirectly proportional to it. Furthermore, no significant differences in the percentage of oil and biodiesel extraction were observed between plant species or irrigation regime.

\section{Conclusions}

The results obtained in this study showed that irrigation with effluent did not result in significant changes in soil $\mathrm{pH}, \mathrm{SOM}, \mathrm{TKN}$, and dehydrogenase activity whereas soil $\mathrm{P}$ was found to increase in the upper soil layer. The soil EC varied slightly throughout the experiment in effluent irrigated pots but no change was detected at the end of the experiment compared to the initial value suggesting sufficient salt leaching. Little differences between effluent and freshwater irrigated pots were observed with regard to soil parameters examined in this study. Thus, pots irrigated with effluent were found to have higher soil EC, P, and dehydrogenase activity compared to those irrigated with freshwater. In contrast, pots irrigated with freshwater had slightly higher SOM and TKN content. This result suggests that the effluent, through $\mathrm{C}$ and $\mathrm{N}$ additions, probably stimulated the growth of soil microorganisms which in turn induced mineralization of organic matter in the soil, as was also indicated by the higher dehydrogenase activity in effluent irrigated pots. With regard to plant species, only minor effects on soil properties were observed with sunflower showing greater values of SOM and TKN than castor bean. This effect provides evidence of differences between plant species with regard to microbial biomass, communities, and activities related to $\mathrm{C}$ and $\mathrm{N}$ mineralization in the soil. With regard to seed yield, it was higher in freshwater irrigated pots compared to that in pots irrigated with effluent probably due to the lower level of soil salinity. Plant species significantly affected the seed yield in this study with castor bean showing greater yield compared to sunflower. Biodiesel production followed the pattern of seed yield.

In conclusion, the findings of this study suggest that wastewater effluent can constitute an important source of irrigation water and nutrients for bioenergy crop cultivations with minor adverse impacts on soil properties and seed yield. Plant species play an important role with regard to the changes in soil properties and to the related factors of seed and biodiesel yields. Further research is needed in order to elucidate the effect of plant species on microbial biomass and communities which mediate $\mathrm{C}$ and $\mathrm{N}$ turnover in soil and nitrogen assimilation in plant biomass, affecting $\mathrm{N}$ cycling and losses (as nitrates or $\mathrm{NO}_{\mathrm{x}}$ gases) to the environment. Knowledge provided would help in successful selection of 
bioenergy crops and management practices ensuring sustainable yield with minor adverse environmental impacts arising from the use of the effluents.

\section{References}

1. European Commission (EC). Renewable Energy Road Map. Renewable Energies in the 21st Century: Building a More Sustainable Future. EC: Brussels, Belgium, 2007; p. 20.

2. Bozbas, K. Biodiesel as an alternative motor fuel: Production and policies in the European Union. Renew. Sust. Energ. Rev. 2008, 12, 542-552.

3. Canoira, L.; García Galeán, J.; Alcántara, R.; Lapuerta, M.; García-Contreras, R. Fatty acid methyl esters (FAMEs) from castor oil: Production process assessment and synergistic effects in its properties. Renew. Energy 2010, 35, 208-217.

4. Berman, P.; Nizri, S.; Wiesman, Z. Castor oil biodiesel and its blends as alternative fuel. Biomass Bioenergy 2011, 35, 2861-2866.

5. Hincapie, G.; Mondragon, F.; Lopez, D. Conventional and in situ transesterification of castor seed oil for biodiesel production. Fuel 2011, 90, 1618-1623.

6. McLaughlin, S.B.; Walsh, M.E. Evaluating environmental consequences of producing herbaceous crops for bioenergy. Biomass Bioenergy 1998, 14, 317-324.

7. Paranychianakis, N.V.; Angelakis, A.N.; Leverenz, H.; Tchobanoglous, G. Treatment of wastewater with slow rate systems: A review of treatment process and plant functions. Crit. Rev. Environ. Sci. Technol. 2006, 36, 1-73.

8. Cantrell, K.B.; Stone, K.C.; Hunt, P.G.; Ro, K.S.; Vanotti, M.B.; Burns, J.C. Bioenergy from coastal bermudagrass receiving subsurface drip irrigation with advance-treated swine wastewater. Bioresour. Technol. 2009, 100, 3285-3292.

9. Heller, M.C.; Keoleian, G.A.; Volk, T.A. Life cycle assessment of a willow bioenergy cropping system. Biomass and Bioenergy 2003, 25, 147-165.

10. Hooda, A.K.; Weston, C.J.; Chen, D. Denitrification in effluent-irrigated clay soil under Eucalyptus globulus plantation in South-Eastern Australia. Aust. For. Ecol. Manag. 2003, 179, 547-558.

11. Bond, W.J. Effluent irrigation-An environmental challenge to soil science. Aust. J. Soil Res. 1998, 36, 543-555.

12. Pierzynski, G.M.; Gehl, K.A. Plant nutrient issues for sustainable land application. J. Environ. Qual. 2005, 34, 18-28.

13. Guo, L.B.; Sims, R.E.H.; Horne, D.J. Biomass production and nutrient cycling in Eucalyptus short rotation energy forests in New Zealand. I. Biomass and nutrient accumulation. Bioresour. Technol. 2002, 85, 273-283.

14. Nannipieri, P.; Ascher, J.; Ceccherini, M.T.; Landi, L.; Pietramellara, G.; Renella, G.; Valori, F. Effects of root exudates in microbial diversity and activity in rhizosphere soils. In Molecular Mechanisms of Plant and Microbe Coexistence; Nautiyal, C.S., Dion, P., Eds.; Springer: Berlin, Germany, 2008.

15. Tzanakakis, V.E.; Paranychianakis, N.V.; Angelakis, A.N. Nutrient removal and biomass production in land treatment systems receiving domestic effluent. Ecol. Eng. 2009, 35, 1485-1492. 
16. Tzanakakis, V.A.; Paranychianakis, N.V.; Londra, P.; Angelakis, A.N. Effluent application to the land: changes in soil properties. Ecol. Eng. 2011, 37, 1757-1764.

17. Lado, M.; Ben-Hur, M. Treated domestic sewage irrigation effects on soil hydraulic properties in arid and semiarid zones: A review. Soil Till. Res. 2009, 106, 152-163.

18. Leal, R.M.P.; Herpin, U.; Fonseca, A.F.D.; Firme, L.P.; Montes, C.R.; Melfi, A.J. Sodicity and salinity in a Brazilian Oxisol cultivated with sugarcane irrigated with wastewater. Agric. Water Manag. 2009, 96, 307-316.

19. Filip, Z. International approach to assessing soil quality by ecologically-related biological parameters. Agric. Ecosyst. Environ. 2002, 88, 169-174.

20. Chen, W.; Wu, L.; Frankenberger, W.T., Jr.; Chang, A.C. Soil enzyme activities of long-term reclaimed wastewater-irrigated soils. J. Environ. Qual. 2008, 37, 36-42.

21. Clesceri, L.S.; Eaton, A.D.; Greenberg, A.E.; Franson, M.A.H. Standard Methods for the Examination of Water and Wastewater, 19th ed.; American Public Health Association: Washington, DC, USA, 1995.

22. Methods of Soil Analysis, Part 2: Chemical and Microbiological Properties, 2nd ed.; Page, A.L., Miller, R.H., Keeney, D.R., Eds.; American Society of Agronomy, Soil Science Society of America, Inc.: Madison, WI, USA, 1982.

23. Casida, L.E.; Klein, D.A.; Santoro, T. Soil dehydrogenase activity. Soil Sci. 1964, 98, 371-376.

24. Ali, A.; Afzal, M.; Rasool, I.J.; Hussain, S.; Ahmad, M. Sunflower (Helianthus annuus L.) Hybrids performance at different plant spacing under agro-ecological conditions of Sargodha, Pakistan. In International Proceedings of Chemical, Biological and Environmental Engineering of the 2011 International Conference on Food Engineering and Biotechnology, Bangkok, Thailand, 7-9 May, 2011; IACSIT Press: Singapore, 2011; Volume 9, pp. 317-322.

25. Soratto, R.P.; Souza-Schlick, G.D.; Fernandes, A.M.; Zanotto, M.D.; Crusciol, C.A.C. Narrow row spacing and high plant population to short height castor genotypes in two cropping seasons. Ind. Crop. Prod. 2012, 35, 244-249.

26. Akaranta, O.; Anusiem, A.C.I. A bioresource solvent for extraction of castor oil. Ind. Crop. Prod. 1996, 5, 273-277.

27. Brady, N.C.; Weil, R.R. The Nature and Properties of Soil, 14th ed.; Pearson Education, Inc.: Cranbury, NJ, USA, 2008.

28. Jueschke, E.; Marschner, B.; Tarchitzky, J.; Chen, Y. Effects of treated wastewater irrigation on the dissolved and soil organic carbon in Israeli soils. Water Sci. Technol. 2008, 57, 727-733.

29. Kuzyakov, Y. Review: Factors affect priming effect. J. Plant Nutr. Soil Sci. 2002, 165, 382-396.

30. Strickland, M.S.; Lauber, C.; Fierer, N.; Bradford, M.A. Testing the functional significance of microbial community composition. Ecology 2009, 90, 441-451.

31. Zak, R.; Holmes, W.E.; White, D.C.; Peacock, A.D.; Tilman, D. Plant diversity, soil microbial communities and ecosystem function: Are there any links? Ecology 2003, 84, 2042-2050.

32. Alkorta, I.; Garbisu, C. Phytoremediation of organic contaminants in soils. Bioresour. Technol. 2001, 79, 273-276.

33. Livesley, S.J.; Adams, M.A.; Grierson, P.F. Soil water nitrate and ammonium dynamics under a sewage effluent-irrigated Eucalyptous plantation. J. Environ. Qual. 2007, 36, 1883-1894. 
34. Phillips, I.R. Phosphorus sorption and nitrogen transformation in two soilstreated with piggery wastewater. Aust. J. Soil Res. 2002, 40, 335-343.

35. Tzanakakis, V.E.; Paranychianakis, N.V.; Angelakis, A.N. Performance of slow rate systems for treatment of domestic wastewater. Water Sci. Technol. 2007, 55, 139-147.

36. Truu, M.; Truu, J.; Heinsoo, K. Changes in soil microbial community under willow coppice: The effect of irrigation with secondary-treated municipal wastewater. Ecol. Eng. 2009, 35, 1011-1020.

37. Zaman, M.; Cameron, K.C.; Di, H.J.; Inubushi, K. Changes in mineral N, microbial biomass and enzyme activities in different soil depths after surface applications of dairy shed effluent and chemical fertilizer. Nutr. Cycl. Agroecosyst. 2002, 63, 275-290.

38. Niu, Z-X.; Sun, L.-N.; Sun, T.-H.; Li, Y.-S.; Wang, H. Evaluation of phytoextracting cadmium and lead by sunflower, ricinus, alfalfa and mustard in hydroponic culture. J. Environ. Sci. 2007, 19, 961-967.

39. Sailaja, M.; Tarakeswari, M.; Sujatha, M. Stable genetic transformation of castor (Ricinus communis L.) via particle gun-mediated gene transfer using embryo axes from mature seeds. Plant Cell Rep. 2008, 27, 1509-1519.

40. Laureti, D.; Fedeli, A.-M.; Scarpa, G.-M.; Marras, G.-F. Performance of castor (Ricinus communis L.) cultivars in Italy. Ind. Crop. Prod. 1998, 7, 91-93.

41. Koutroubas, S.D.; Papakosta, D.K.; Doitsinis, A. Adaptation and yielding ability of castor plant (Ricinus communis L.) genotypes in a Mediterranean climate. Eur. J. Agron. 1999, 11, 227-237.

42. Kumar, P.V.; Ramakrishna, Y.S.; Ramana Rao, B.V.; Victor, U.S.; Srivastava, N.N.; Subba Rao, A.V.M. Influence of moisture, thermal and photoperiodic regimes on the productivity of castor beans (Ricinus communis L.). Agr. For. Meteorol. 1997, 88, 279-289.

43. Duke, J.A. Handbook of Legumes of World Economic Importance; Plenum Press: New York, NY, USA; London, UK, 1981; pp. 195-200.

44. Patzek, T.W.; Pimentel, D. Thermodynamics of energy production from biomass. Crit. Rev. Plant Sci. 2005, 24, 327-364.

45. Göksoy, A.T.; Demir, A.O.; Turan, Z.M.; Dağüstü, N. Responses of sunflower (Helianthus annuus L.) to full and limited irrigation at different growth stages. Field Crop. Res. 2004, 87, 167-178.

(C) 2011 by the authors; licensee MDPI, Basel, Switzerland. This article is an open access article distributed under the terms and conditions of the Creative Commons Attribution license (http://creativecommons.org/licenses/by/3.0/). 